\title{
FAMILY WITH CHILDREN IN TIMES OF PANDEMIC - WHAT, WHERE, HOW? DILEMMAS OF ADULT-IMPOSED PROHIBITIONS AND ORDERS
}

\author{
URSZULA MARKOWSKA-MANISTA ${ }^{1} \&$ DOMINIKA ZAKRZEWSKA-OLĘDZKA ${ }^{2}$ \\ ${ }^{1}$ University of Warsaw, Faculty of Education, Mokotowska 16/20, Warsaw, Poland. ORCID 0000-0003- \\ 0667-4164, Email: u.markowska-ma@uw.edu.pl \\ ${ }^{2}$ The Maria Grzegorzewska University, Institute of Psychology, Szczęśliwicka 40, 02-353 Warsaw, \\ Poland. ORCID: 0000-0003-2744-7905, Email: dzakrzewska@aps.edu.pl
}

ABSTRACT: The coronavirus has closed adults and children at home. We communicate by phone or the Internet. Life has moved online, it has lost its rhythm within traditional systems of school and work. As a result of the COVID-19 pandemic spreading around the globe, many states have introduced numerous limitations in adults' and children's social functioning. The majority of education and care institutions have been closed, while companies and institutions whose type of activity allows to do so have decided to transform their work patterns into remote work. This new situation has particularly affected children, who, for their own and their families' safety, have been cut off from the possibility to participate in activities and events that used to be part of their daily lives. In order to look at this situation and analyse the situation of families with children, an online survey questionnaire was conducted among 158 adults that aimed to collect data from below (from the perspective of reflexive adults looking after children in the situation of spatial-mobile limitations). In the article, we discuss changes in parents' and children's lives and analyse the social background of the areas discussed.

KEYWORDS: children, right to nondiscrimination, epidemic, online activities and spatial-mobile limitations, prohibitions and orders 


\section{INTRODUCTION}

We cannot solve our problems with the same thinking we used when we created them.

Albert Einstein

The coronavirus has been spreading since December 2019. An epidemic unseen since over a hundred years ago (in 1918-1919, the Spanish flu killed at least 50 million people around the world) lulled the vigilance of authorities and surprised populations on all continents. Panic among the authorities and societies - in the wake of regulations and decisions holding the view that isolation is the best policy to control the virus - has locked adults and children in their homes. Particular states introduce new restrictions in order to reduce the spread of the coronavirus. With regard to the growing number of infections in Poland, on March 24th 2020 the government introduced travel restrictions: banning people from leaving their homes without vital need (such as going to work, buying essential food and hygiene products or a visit at the chemist's). Parks, forests, playgrounds and riverside boulevards have been closed. As the minister of health informed, regulations concerning church services, funerals and public transport would also be tightened. It is only the top of the iceberg as a tendency to extreme behaviours is revealed in crisis situations.

In Poland, we are currently moving from the so-called alarm stage of stress to adaptation stage of stress connected with the coronavirus (Łoza 2020). The first stage happened spontaneously. It was surprising, and for the majority of people - frightening news they reacted to instinctively for instance by purchasing many vital products such as toilet paper, oil or pasta. In the adaptation stage, we adjust to the new, uncertain reality. It is a stage of responding to and managing the threat through various behaviour strategies and expression tools. It involves being hyperactive on social network sites, posting memes about the epidemic, playing instruments or singing on balconies, but also resistance and rebellion against the new reality that shattered our safe daily lives. Adaptation stage is simultaneously a period of waiting for the next stage in which we anticipate the eradication of the causes of stress, development of constructive strategies of coping with the present situation, or one in which we lose internal resources leading to exhaustion stage.

Suspended in the new reality while being closed at home, we communicate by phone or the Internet. We try to adapt to the new challenges and tasks. Adults' and children's lives have moved online to an even greater degree, lost their rhythm of traditional preschool, school and professional functioning. Suddenly, we have been pulled out of our daily rituals and responsibilities and held back in place, in the 'comfort' of our homes. Rush, mobility, a chase after what seemed the most important halted. Due to the COVID-19 pandemic spreading worldwide, many EU countries have closed their borders. Numerous restrictions in adults' and children's social functioning have been imposed. The majority of education and care institutions have been closed, while companies and institutions whose work forms allowed to do so have introduced remote work patterns. This new situation has particularly affected children, who - for 
their own and their families' safety - have had their freedom to play with their peers, participate in regular activities and events taken away. Additionally, we have found ourselves in a narrative construction of this crisis escalated by the media highlighting the words 'virus', 'plague', 'quarantine', 'social distancing', 'sanitary crisis', 'death', 'war', 'epidemic' or 'invisible enemy'.

\section{WHAT? WHERE? HOW?}

Ensuring equality de jure does not necessarily lead to de facto equality.

(see Liebel et al. 2014: 16)

In the situation of a sudden crisis, problems, inequality and discrimination do not vanish - they are exacerbated. Those weakest and youngest, frequently overlooked or ignored by adults in their adultist approach: children, are the most exposed to the negative effects of chaos and disorganisation. It is particularly visible in times of crisis both in the dimension of media discourse and top-down activities oriented towards adults. Additionally, the majority of adults find it difficult to navigate the radically new context of functioning. Trying to cope with their new reality, they are partly unaware of how and what challenges young people (their children) face every day. They are frequently unaware of their own approach towards children - their own reactions or lack thereof in crisis situations such as an epidemic. Among those in particularly dramatic situations are families and children who, with regard to their origin, difficulties connected with material situation or living in dysfunctional, educationally deficient backgrounds, could not in the past and today still cannot count on the support of their close ones or whose close ones are an actual threat.

The traditional approach (prefigurative and cofigurative culture), in which knowledge is transferred from adults to children, is proving ill-suited in the increasingly more digitalised society in which young people usually have better digital competences than their parents (prefigurative culture). However, stress and a sense of responsibility for those under adults' care generated by the crisis situation inhibit the implementation of participatory approach and attempts to creatively solve the emerging challenges for instance in the system of remote education. Even if such an approach were undertaken, implementing might not be successful in the situation when digital exclusion, understood as lack or limited access to modern forms of communication and information technologies (Motylińska 2019), is largely correlated in Poland to age, and mean age of teachers in Polish society is increasing. In the school year 2018/2019, mean age of teachers in Poland was 44,1 (Glos Nauczycielski 2019), reaching approximately the age of the generation of present parents of primary and secondary school students. Digital exclusion can result from lack of competences, reluctance to embrace new technologies or financial limitations. In the context of school environment, lack of or low digital competences among teachers, in addition to limiting the possibilities of enriching the learning process, are also frequently the reason for a lack of understanding between the teacher and students. They also make it difficult for teachers to comprehend the nuances in the functioning of student groups connected with virtual 
reality (e.g. aspects related to cyber violence which, in this age group, often takes place on social media websites where teachers are not, do not want to be or do not know how they could be present).

Observation of Polish educational reality allowed scholars to conclude that "teachers and academic lecturers are still reluctant to use or are ineffective at using digital education tools that support the teaching process” (Głomb and Kniaź 2019), while two thirds of classes in Polish schools have a form of lectures that facilitate neither students' activity nor taking full advantage of the potential of digital tools and applications. In a 2014 study on the use of information and communication technology in didactic work, despite the fact that the majority of respondents expressed positive opinions about the potential of new technologies and declared that they frequently used the Internet to search for teaching resources, multimedia resources and to expand their knowledge, only $26,3 \%$ of them used information and communication technologies to prepare online lessons. This, along with the fact that many teachers do not have their own e-mail account, can be an indication of digital exclusion (Kochan 2016). Unfortunately, reports from recent months confirm that since the study cited above, there has been no considerable change in this aspect (Sewastianowicz 2019).

In this context, overnight, we found ourselves in a situation where due to the epidemic, the majority of social and professional life has been moved to the Internet. Almost immediately, the Ministry of Education obliged teachers to conduct remote teaching. In the crisis situation which is in itself a source of considerable fear and uncertainty, teachers were additionally challenged with the necessity to move far beyond their comfort zones and rapidly adapt to remote teaching, while having to simultaneously look after their own children. As a result, the parents were initially flooded with assignments sent by teachers, which brought on a sense of frustration, particularly when they were unable to take time off work to look after their children.

Only some children and adolescents can complete the tasks offered by the school (in various forms) in a fully independent manner. Only some parents have the possibility to accompany their children in their education at home. Other parents have their own professional responsibilities, still others are unable to cope with the challenges (being overloaded with physical work, lacking skills to do remote work). There are also those who cannot sufficiently support their children in remote education due to various other factors (small flats, difficult living conditions, lack of access to computers, illness, lack of knowledge of Polish among foreign families).

Access to the Internet and devices enabling the use of the Internet is the basic condition to work and learn online. In this regard, the situation in Poland seems to be very good. According to a GUS (Central Statistics Office) survey "Information society in Poland in 2019", 86,7 \% of households had Internet access, while 83,1 \% of households had at least one computer. The factor that played the greatest role in the availability of the Internet and computer equipment was the presence of children in a particular household (99,3\%), which supports the thesis put forward earlier in the text that young householders inspired the development of their families' digital competences. It is also worth pointing out that members of roughly $50 \%$ of the households without access to the Internet indicated lack of digital competences as the reason for 
the lack of network connection. In recent years, the program of the Ministry of Education "Digital School" resulted in a series of activities being implemented to enable the school environment to take advantage of amenities offered by new technologies (the program involved e.g. trainings for teachers and students, equipping schools with electronic equipment and installing Internet connections at schools). The ministerial website even offers e-textbooks and online lessons enabling students to become familiar with learning material on particular stages of education.

However, as researchers from the Telecommunication Development Bureau argue, access to the Internet and Internet devices alone is not enough to effectively use its resources and simultaneously protect ourselves against its potential threats. Lack of ICT skills is the key barrier in this regard. As results from Measuring the Information Society Report. Facts and figures 2019 conducted between 2014 and 2018, in 40 out of 84 countries around the world included in the study less than half of the population had basic computer skills (e.g. copying a file or sending an e-mail with an attachment). Unlike the level of access to the Internet, which, despite being lower than European average can still be perceived as relatively high, when it comes to digital competences of the society, Poland ranks much lower than the majority of European countries. Only $25-50 \%$ of Polish citizens have basic and standard computer skills and $0-5 \%$ advanced computer skills, and the level of digital competences is correlated with age.

The crisis we face within our families plays out on various dimensions: social, cultural, political, educational, psychological and interpersonal. It involves, inter alia, the fact that the traditional daily routines, habits and patterns and the old tools that worked up to this moment, are failing to function in the new situation. This crisis has its own dynamics. The present phase of confronting a phenomenon previously unknown to us reflects a whole spectrum of inefficiencies of the strategies we use to cope with the new reality and take responsibility for the newly emerging challenges. This chaos, uncertainty and fear of the unknown much as the absence of familiar order leads to growing tensions, anxiety, irritation, helplessness and frustration. Some families assume that they are unable to cope with the multiple new challenges. They experience a sense of chaos, inability to take decisions while focusing on negative information that aggravates panic. Other families look for strategies to handle the difficulties. They move on to mobilisation stage and initiate all available coping resources.

And yet, we have to bear in mind that preschool and school children make up a large part of family members in Poland. Through the so-called "protective" measures, they have been closed in their homes. Children, their parents and guardians react to the crisis in various ways. They share the common (government-imposed) order to stay in and prohibition to leave their homes without a vital reason. They differ in how they comply with orders and prohibitions in daily functioning, both on national and family level, as in many families the decisions about daily life have been made by adults without inviting their children to join the dialogue.

\section{PROCEDURE, METHODS AND RESEARCH SAMPLE}

In the second half of March 2020, we conducted research in quantitative-qualitative 
paradigm. It was preceded by thematic desk research involving a review of vital literature, publicly available scientific, official and third sector data generated by various entities about the situation of children in families in times of an epidemic as well as media and political information connected with the epidemic.

The quantitative-qualitative study was conducted through an online tool. It was a survey questionnaire with open- and closed-ended questions (12 questions: 6 in the child's section and 6 in the parent's section). The tool consisted of an instruction, background data questions, a section describing the situation of parents, a section describing the situation of children from the parents' perspective, and a section with additional parents' reflections and acknowledgments for completing the survey.

In order to select the sample for the survey questionnaire available online, we applied the snowball method ensuring maximum variability within the sample, i.e. inviting parents who speak Polish and live in various parts of the country to participate in the study. The total research sample was 158.

\section{ETHICS}

All research participants were informed about research aims and ensured that the data collected would be used only for academic purposes and to prepare a research report.

The study carried out through a survey questionnaire provided information that the participation was fully voluntary. The respondents were able to refuse participation both before the study and while answering the survey questions. The questions did not address controversial issues, nor did they have a negative influence on the participants. The invitation (to adults) to answer the survey questions did not burden our respondents. On the contrary, many of them included comments that the questions prompted them to reflect on their reactions towards children in the situation of the epidemiological crisis.

The respondents' personal data were not used in any report. Following research ethics and the participants' wellbeing on every stage of the study, we were available for the respondents answering the survey questions.

\section{LIMITATIONS}

Problematic aspects of conducting the study included Internet access and digital competences, which limited our research sample. Some of the respondents perceived filling in the survey during the day as a problematic waste of time and energy and decided to answer the questions in the evening/at night (when the children were asleep). The survey was distributed mainly through social media and e-mail addresses among Polish people. Those who do not use these forms of communication were unable to learn about the study or participate in it. We realise that we did not reach parents who do not use these communication methods but who would want to share their experiences based on which projects supporting families could be designed.

Another issue concerns individuals who, for various reasons, are not interested in their children. These parents are unlikely to participate in this type of study. This 
is also true about parents who are too burdened with responsibilities (remote work, additional duties) or those whose digital competences are insufficient to learn about this type of survey and to fill it in on the Internet. Also, in the situation when a close emotional bond between parents and children is missing or when mutual understanding and trust are absent from the relations between parents and children, the parents' assessment of emotions that the present situation evokes in children may not fully reflect what the children actually experience. It was our intention to conduct the study from the perspective of adults. We took a position that research done in the sensitive context of an epidemic should not burden children. Despite the child's right to reliable information enshrined in the Convention on the Rights of the Child (1989), this group of citizens did not receive this type of information from the authorities (Ombudsman for children, the minister of education). We realise that conducting the study among children might have revealed other problem areas than those indicated by the parents, yet we were motivated by the children's wellbeing (in terms of not interfering in sensitive subjects that might additionally influence or disturb their sense of security), which, particularly in the first stage of adapting to a life in the conditions of an epidemic and lack of possible psychological support, should protect children against additional negative consequences and impact of activities initiated by adults (more: Liebel and Markowska-Manista 2017).

\section{FINDINGS}

\section{RESEARCH SAMPLE STRUCTURE}

The analysis considered the situation of parents through their subjective evaluation and the situation of children from the perspective of their parents. Women constituted the vast majority of the respondents ( $85,7 \%$ vs men $13,3 \%)$. The age of a significant number of the participants ranged from 30 to 39 (46,2\%) and 40 to 49 (46,8\%). The remaining age groups were represented by a much smaller number of respondents, respectively $20-29$ years old (4,4\%), $50-59$ years old $(2,5 \%), 60-69$ years old $(0.6 \%)$. The answers were provided primarily by individuals with university education (87\%), which can be seen as one of the limitations of this study. Persons with secondary education constituted only $12 \%$ of the respondents and adults with vocational education $1 \%$. The respondents represented various professions (e.g. businesses employees, managers, teachers, NGO staff, postmen, accountants, academic teachers). The majority of the participants are residents of urban (38\%) and rural (31,5\%) areas. The remaining respondents live in small (7,6\%), medium-sized (12\%) and large cities (10,8\%). 92\% of the respondents are married or in partnerships, while $8 \%$ are single parents. The majority of households consisted of 2 adults (58\%) [Fig. 1] and 2 (58\%) or 1 (27\%) children [Fig. 2], while the children's age oscillated between several months to 22 years old (studying children were also included in the study). 52\% of the participants live in blocks of flats, while $48 \%$ in detached houses. As far as children's own space in the house is concerned, the majority of the children (93\%) have their own rooms. 
Figure 1. Number of adults in a household

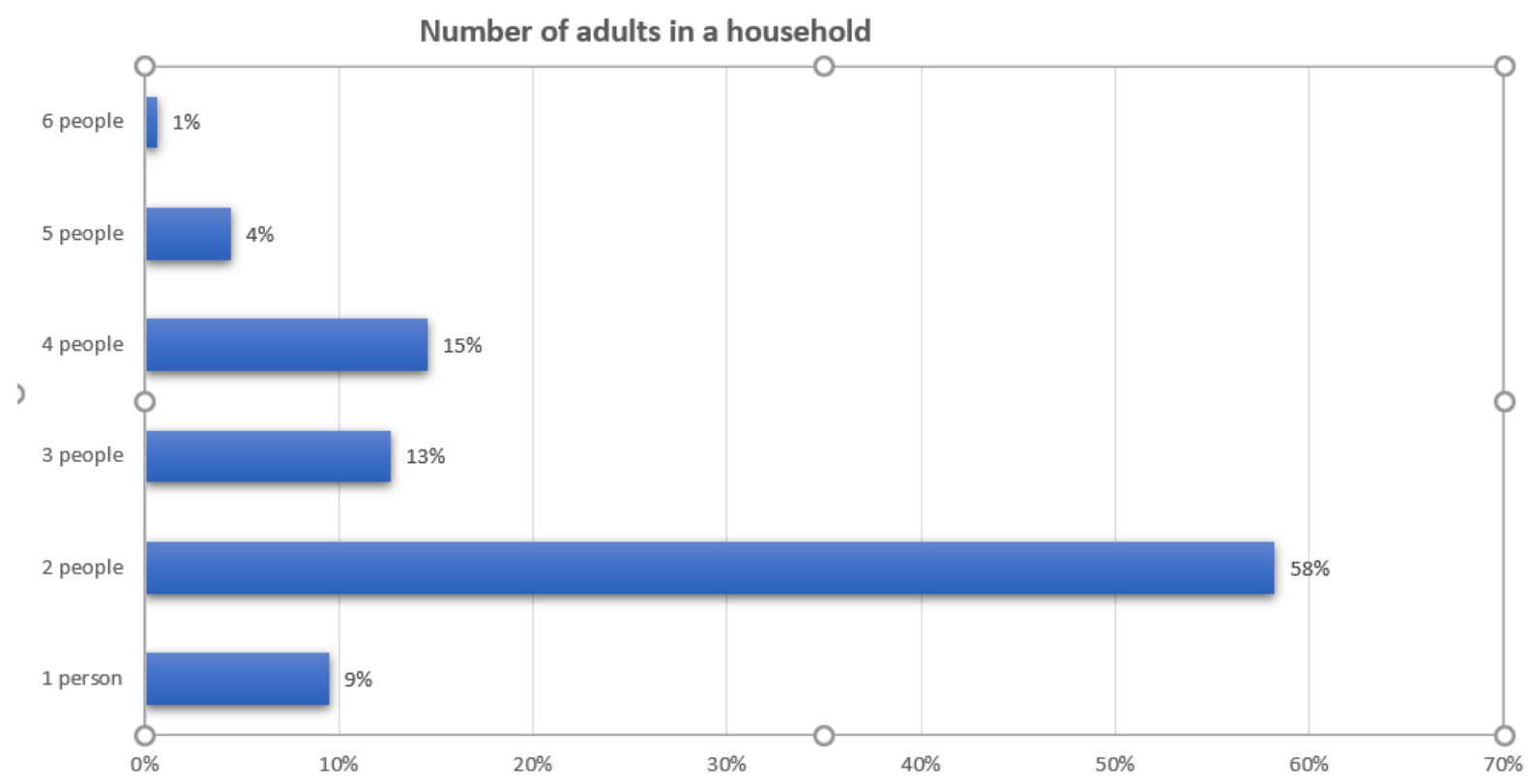

Source: own elaboration.

Figure 2. Number of children in a household

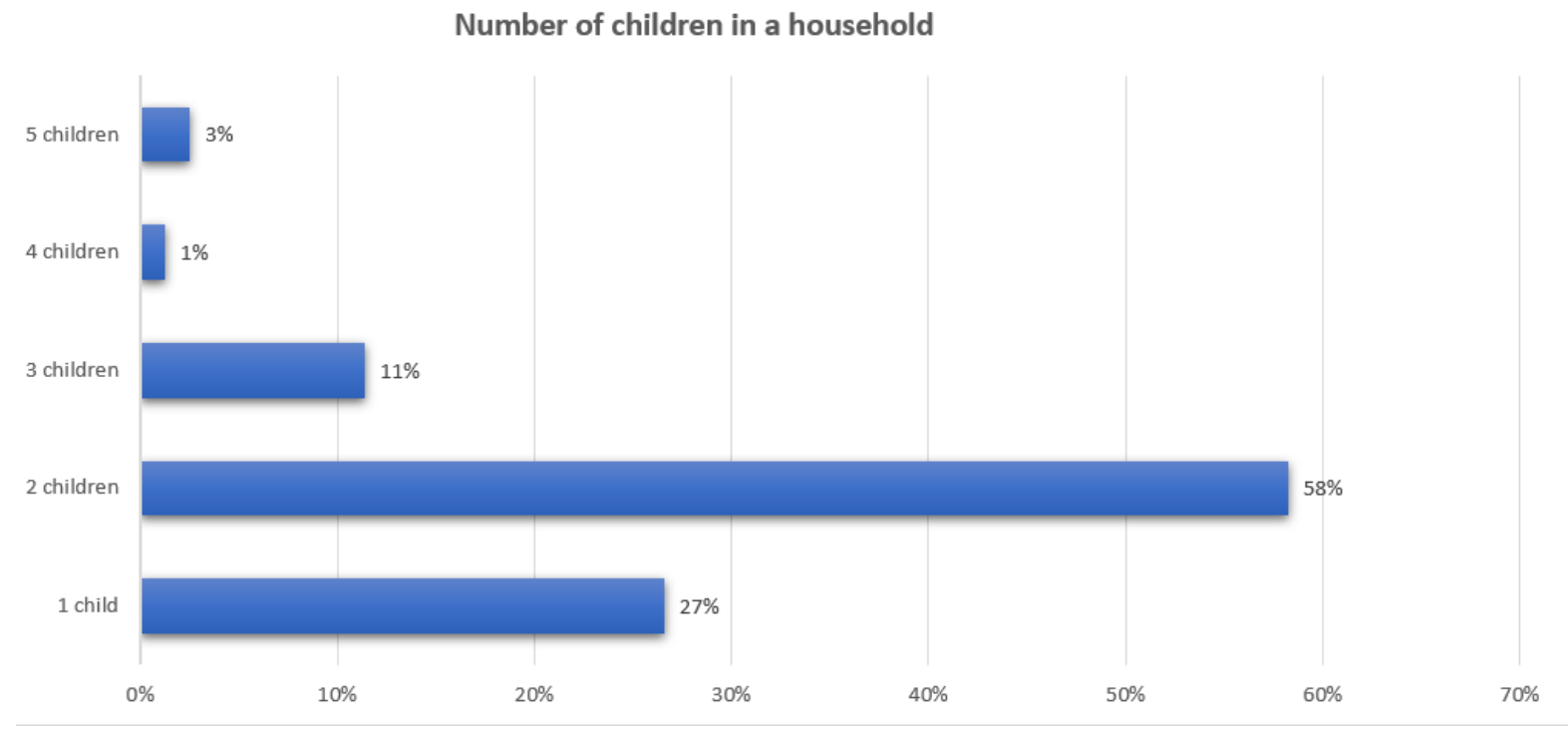

Source: own elaboration.

\section{THE SITUATION OF PARENTS}

\section{FULFILLING PROFESSIONAL DUTIES DURING THE CORONAVIRUS EPIDEMIC}

The majority of parents who participated in the study are professionally active (73\%). Over a half of them (54\%) work online [Fig. 3]. This means that they have to combine childcare, assisting the children in learning and completing the assignments sent by teachers with full-time remote work that requires access to adequate technology (In- 
ternet connection, computer equipment). Approximately one fifth (19\%) of the parents still fulfil professional duties at business premises. In the case of this group of parents, childcare seems particularly demanding in terms of logistics since according to existing regulations introduced with regard to the coronavirus epidemic, only parents of children below the age of 8 are entitled to childcare leave. In the case of older children, despite the fact that parents are responsible for this age group as well, they are unable to take advantage of paid childcare leave. In the situation where many companies suspend or limit their activities in the face of the commencing crisis, very few parents are willing to take the risk of losing a steady income having a family to support, while often being also financially burdened with mortgage.

Figure 3. Performing professional duties during the coronavirus epidemic

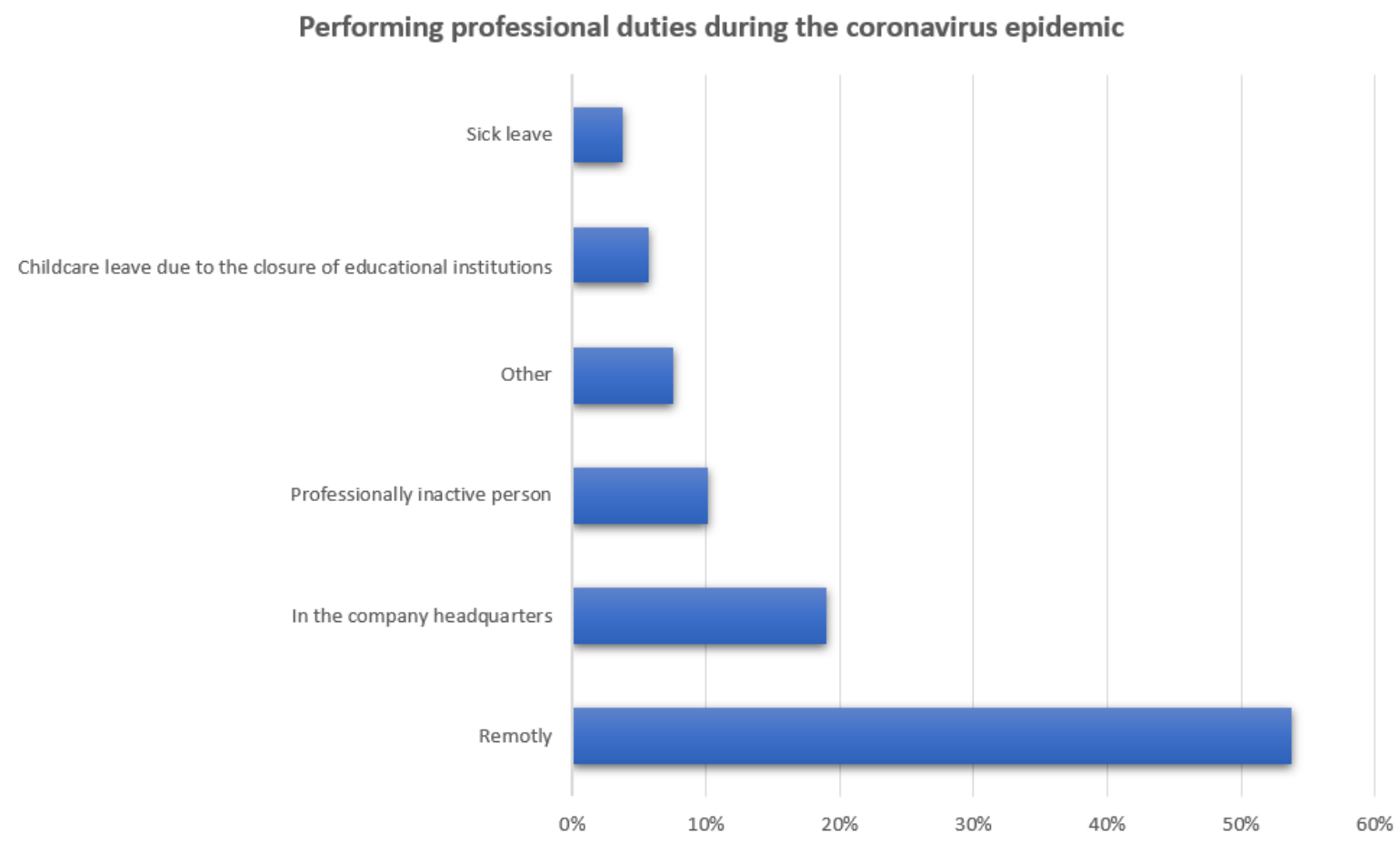

Source: own elaboration.

\section{WHAT IS THE MOST PROBLEMATIC FOR THE RESPONDENTS `AT PRESENT MOMENT'?}

Among the most challenging problems in the present situation indicated by the parents (the study was conducted between 24-28 March 2020) is the necessity to combine online work with childcare. They point to the lack of possibility of focusing on professional duties while having to provide care to their children, organising their time in an interesting and creative way and helping them with learning and completing the assignments sent by teachers. Many parents also indicated that while they had more time to spend with their children, the child's natural need to be constantly close to the parents through conversation or cuddling did not allow them to concentrate ad- 
equately on professional duties, which reduced their work efficiency. It is also visible in other aspects listed as challenging such as time management and childcare (12\%), or helping children with completing school tasks and motivating them to learn, and poor organisation of online teaching (13\%). The parents also commented that if the lessons online were conducted in real time, focusing the child's attention on classes conducted by teachers in an active and engaging way would significantly relieve their responsibilities. If young children receive a task to become familiar with new subjects based on their individual work with textbooks or exercise books, it naturally requires significant contribution from the parents or other caregivers. Lack of possibility to maintain social contact both by adults and children is an additional difficulty reported by the parents (20\%). The respondents drew particular attention to children's sadness caused by the fact that they are not allowed to play with their peers from preschools or with their classmates (to some degree, "live” lessons using online teaching platforms might substitute personal contact), while lack of contact with the children's grandparents was reported as particularly painful.

Table 1. Most problematic issues for parents in the present situation

\begin{tabular}{|l|c|}
\hline & \\
\hline Most problematic issues for parents in the present situation: & \\
\hline $\begin{array}{l}\text { Combining online work with childcare and household duties, lack of adequate conditions to } \\
\text { do remote work }\end{array}$ & $23 \%$ \\
\hline Lack of possibility to move freely and maintain social contact & $20 \%$ \\
\hline $\begin{array}{l}\text { Helping children with completing their school tasks and motivating them to learn, poor or- } \\
\text { ganisation of online teaching }\end{array}$ & $13 \%$ \\
\hline Time management, childcare and organisation of children's time & $12 \%$ \\
\hline Fear for one's own and family's health due to the risk of being infected with the coronavirus & $8 \%$ \\
\hline Anxiety connected with family financial situation and the anticipated economic crisis & $7 \%$ \\
\hline Doing shopping & $5 \%$ \\
\hline Lack of access to basic medical care and rehabilitation & $4 \%$ \\
\hline Lack of mobility & $4 \%$ \\
\hline Lack of digital competences & $3 \%$ \\
\hline Psychological problems & $3 \%$ \\
\hline Work & $3 \%$ \\
\hline Nothing & $2 \%$ \\
\hline Lack of clear information & $2 \%$ \\
\hline
\end{tabular}

Source: own elaboration.

\section{HOW DID YOU EXPLAIN THE PRESENT SITUATION TO YOUR CHILDREN?}

The majority of parents declare that they discuss the situation with their children with openness and honesty. They try to use simple language, explain that a new virus appeared that is still unknown to doctors, how we can become infected, that it produces symptoms similar to flu (cough, fever); some parents also tell their children that the virus can lead to death. For this reason, in order to ensure their own safety and the 
safety of others (older people in particular), they have to restrict leaving their homes and meeting their grandparents as well as friends from school or preschool. They also draw attention to the necessity to maintain hygiene and wash one's hands. Some parents also declare that the children had received basic information about the situation from their school teachers before education at school was suspended. In the case of the youngest children, the parents either do not address this situation at all (if they believe that the child is too young to understand it), or they try to use fairy tales, metaphors or rhymes to explain the seriousness of the situation to their children. Many of them stress that they try to inform, but in a way that would not arouse fear or aggravate a sense of insecurity. There were several cases in which the respondents applied the strategy of imposing restrictions without explanation ("this is how it's supposed to be", "it's not allowed and that's it") or scaring the children, e.g. "If you leave the house you can bring the virus and it can kill me".

\section{HAVE NEW RULES OF FAMILY FUNCTIONING BEEN INTRODUCED AT HOME?}

Only $16 \%$ of the respondents declared that with regard to the epidemic no new rules of family functioning had been introduced at home, and approximately only $10 \%$ of the families in which new rules have been implemented confirmed that they had been consulted with the children. Among the most commonly mentioned new rules were frequent washing of hands and drawing particular attention to hygiene (29\%), limitations in external contacts and leaving the house (27\%), learning online at home due to the closure of schools and preschools (15\%) and organisation of daily routine (12\%).

Table 2 . New rules for the functioning of the family

\begin{tabular}{|l|c|}
\hline & \\
\hline New rules for the functioning of the family: & \\
\hline Hygiene (frequent hand washing) & $29 \%$ \\
\hline Limiting external contacts and leaving home & $27 \%$ \\
\hline No school, learning online & $15 \%$ \\
\hline Organisation of daily routine & $12 \%$ \\
\hline Disinfection of objects brought from outside & $6 \%$ \\
\hline Additional household duties, more work & $4 \%$ \\
\hline Respecting the need for parents' work, not disturbing & $4 \%$ \\
\hline More time to watch cartoons, tv, use the computer & $2 \%$ \\
\hline Covering your mouth when you sneeze and cough & $1 \%$ \\
\hline Stocking up on food and medicines & $1 \%$ \\
\hline Additional precautions & $1 \%$ \\
\hline Use of contraceptions & $1 \%$ \\
\hline Daily walks with the family & $1 \%$ \\
\hline Rational use of food stocks & $1 \%$ \\
\hline
\end{tabular}

Source: own elaboration. 


\section{HOW HAS THE PRESENT SITUATION CHANGED TIME SPENT WITH THE CHILDREN?}

Half of the parents (51\%) declared that the present imposed social isolation caused by the COVID-19 virus pandemic resulted in the fact that the family spend more time together and have the opportunity to participate in many joint activities such as reading books, playing board games, doing arts, talking, cooking or watching films together, which evokes positive feelings. However, some of the working parents declared that due to the necessity to combine work with childcare, the contact was becoming more tense, while time after work that the parents would normally devote to entertainment and conversation with the children, was now spent explaining school subjects and doing homework. Only $10 \%$ of the parents commented that not much had changed in the time they spend with their children in the new situation as compared to the situation from before the epidemic.

Table 3. How the current situation changed the way in which parents spend time with children

\begin{tabular}{|l|c|}
\hline How has the current situation changed the way you spend time with your children? & \\
\hline $\begin{array}{l}\text { Spending more time together, more joint activities than before (reading books, board games, } \\
\text { manual activities, conversations, cooking together, crossword puzzles, watching movies, } \\
\text { creative games), positive feelings about the impact of restrictions on the amount of time } \\
\text { spent with children }\end{array}$ & $51 \%$ \\
\hline More time spent learning and educating the children & $15 \%$ \\
\hline Nothing or little has changed & $10 \%$ \\
\hline $\begin{array}{l}\text { The need to combine work with childcare, less ,free” time, more responsibilities, private life } \\
\text { is mixed with professional life }\end{array}$ & $8 \%$ \\
\hline All the time spent at home with children 24 hours a day & $6 \%$ \\
\hline Spending time only with family members, limiting social gatherings & $5 \%$ \\
\hline $\begin{array}{l}\text { It is difficult, more frequent conflicts, tensions, a lot of time at home, boredom, being tired } \\
\text { of each other }\end{array}$ & $5 \%$ \\
\hline Going out less & $3 \%$ \\
\hline Children play computer games, watch movies more & $2 \%$ \\
\hline No rush & $1 \%$ \\
\hline Involving children in housework & $1 \%$ \\
\hline More physical closeness (hugging) & \\
\hline
\end{tabular}

Source: own elaboration.

\section{DO YOU USE HELP WITH CHILDCARE?}

The vast majority of the families participating in the study (87\%) do not use any form of help with childcare. A much smaller group are helped by grandparents (14\%), employ babysitters (1\%) or use other firms of help with childcare (1\%). 
Figure 4. Parental use of help with childcare

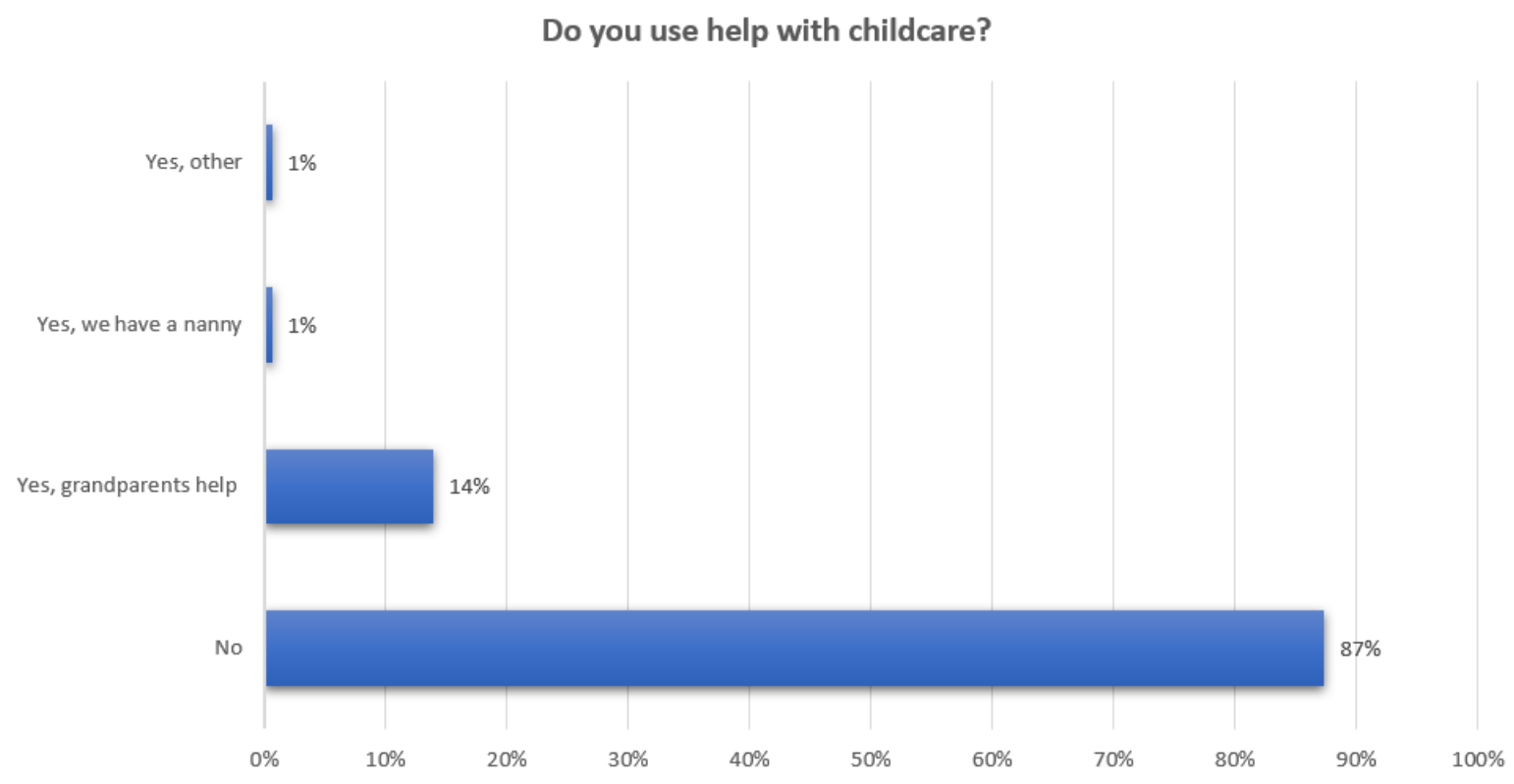

Source: own elaboration.

\section{THE SITUATION OF CHILDREN}

\section{HOW DO CHILDREN REACT TO INFORMATION ABOUT THE EPIDEMIC FROM THE MEDIA?}

The majority of children - aside from those who are too young - notice and understand the subject of the epidemic. There are two strategies emerging that are used by parents who have to face this subject with reference to their children's situation. One of them is an open conversation with their children, answering their questions and explaining that an infectious disease has appeared, as a result of which everyone has to follow extraordinary precautions. The second strategy (used particularly when the parents notice their children's fear and anxiety caused by the information) is to limit access to information in the media and filter the information through the parents who e.g. review the news only once a day when the children are asleep. The majority of children understand the necessity to introduce restrictions at home and outside and follow them. They understand it is a temporary requirement and concerns all people.

\section{DO CHILDREN HAVE THEIR OWN MOBILE PHONES, COMPUTERS AND LAPTOPS?}

Over half of the children from the sample $(56,3 \%)$ have their own mobile phones while a little less than a half (45\%) have computers at their disposal. It is important with regard to the fact that when online learning is required, all family members working and learning online need access to their own work device, in this case a computer or a tablet. Consequently, information that $45 \%$ of children have their own computers simultaneously means that $55 \%$ of children in the families from the research sample are unable to work on the tasks sent by teachers in real time or have to share the computer 
with their parents (who also frequently work online) and their siblings.

Table 4. Children's reactions to information about the epidemic from the media

\begin{tabular}{|l|c|}
\hline How do children react to information about the epidemic from the media? & \\
\hline They are afraid, anxious & $23 \%$ \\
\hline They ask questions, talk about this subjects with the parents & $20 \%$ \\
\hline $\begin{array}{l}\text { With interest (they want to know what is happening and understand the mechanisms of } \\
\text { how the virus works, they follow the trends in infections and deaths, they ask why they } \\
\text { differ in different countries) }\end{array}$ & $18 \%$ \\
\hline With calmness and understanding & $16 \%$ \\
\hline Lack of interest in the subject on children's part & $14 \%$ \\
\hline Limiting the news (and the media) by adults to avoid burdening the children & $11 \%$ \\
\hline Too young to understand & $5 \%$ \\
\hline Rebellion against restrictions, irritation, anticipating the end of the situation & $4 \%$ \\
\hline $\begin{array}{l}\text { Too much information about the virus, avoiding information when it appears (initiated by } \\
\text { the children) }\end{array}$ & $3 \%$ \\
\hline With sadness & $2 \%$ \\
\hline They do not realise the gravity of the situation & $1 \%$ \\
\hline The subject of the coronavirus appears when playing games & $1 \%$ \\
\hline Trust towards public services & $1 \%$ \\
\hline
\end{tabular}

Source: own elaboration.

Figure 5. Do children have their own cell phones?

Do children have their own cell phones?

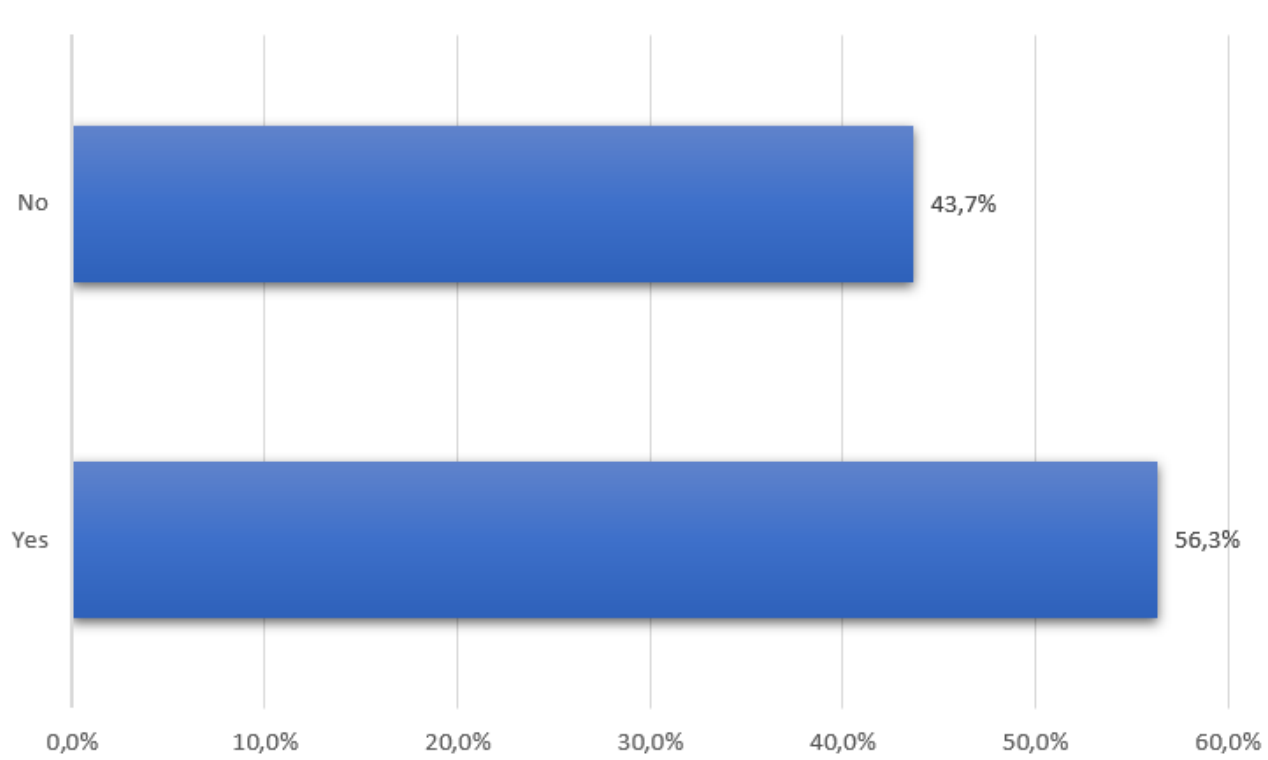

Source: own elaboration. 
Figure 6. Do children have their own computers?

Do children have their own computers?

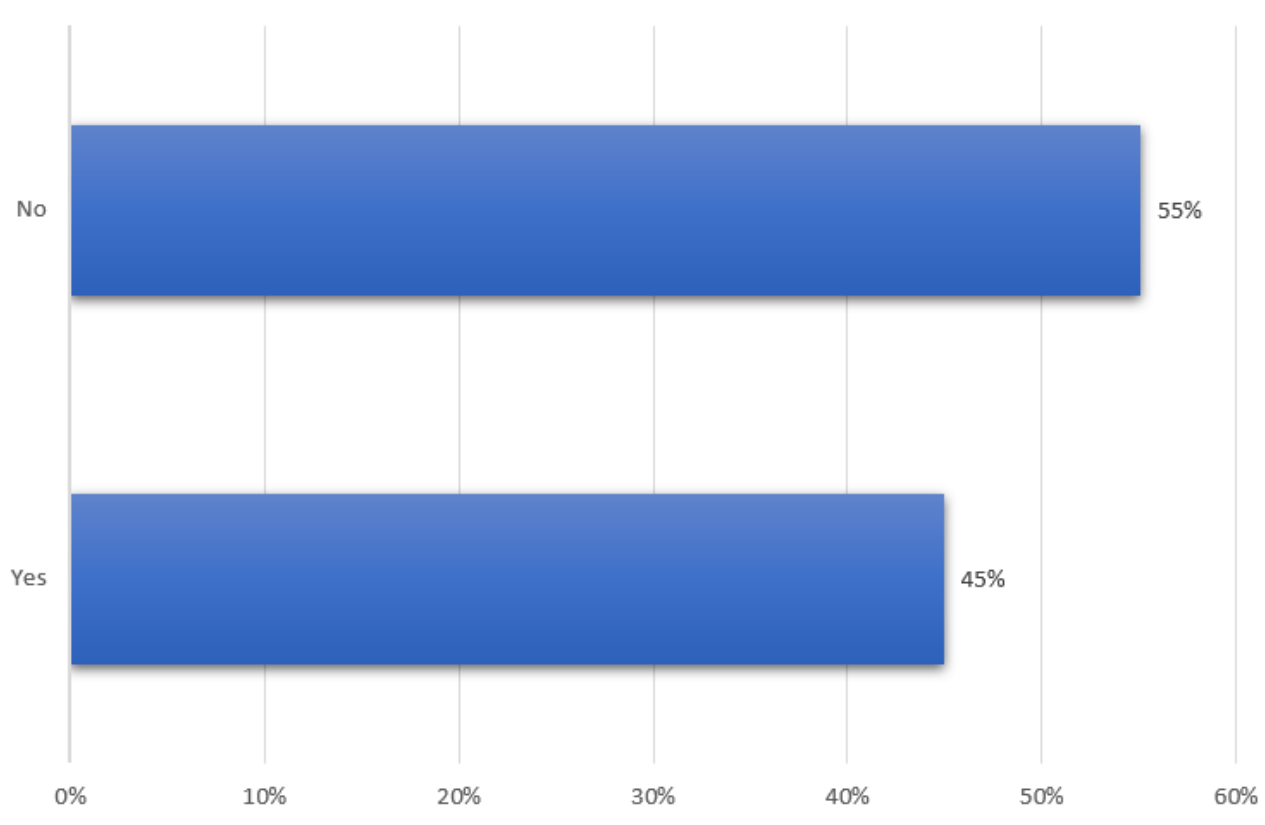

Source: own elaboration.

\section{HOW DO CHILDREN FOLLOW THE SCHOOL CURRICULUM?}

Despite the fact that schools have to conduct online education, this regulation is a dead letter in many schools in the country due to lack of digital competences and lack of access to adequate software and hardware both on the part of teachers and learners. Unlike many more computerized countries, Poland lacks significant experience in implementing distance learning in the structure of public schools, so using online work technology is a new task for much of the school staff, while for many it is a completely new and unchartered territory (apart from using Librus e-teacher diary). As results from the parents' account, many teachers conducts online education by sending a list of homework assignments to students $(67,1 \%)$ and sending information to the parents about topics to be discussed with their children (38,6\%). Situations in which teachers send didactic resources to the students $(42,4 \%)$ or publish tasks on e-learning platforms (38\%) are much more rare. Conducting live online lessons with the class is the rarest form of distance education.

\section{CAN CHILDREN GO OUTSIDE IN THE PRESENT SITUATION?}

The majority of parents declared that children could leave the house only accompanied by an adult caregiver (49\%), while $23 \%$ of the parents do not allow their children to go outside at all. According to the parents' declarations, one fifth (20\%) of the children can leave the house unaccompanied, however on 31st March 2020, a new government regulation was introduced limiting this possibility: underage children (under 
the age of 18) can remain outside only if accompanied by an adult caregiver.

Figure 7. Do children follow educational curriculum?

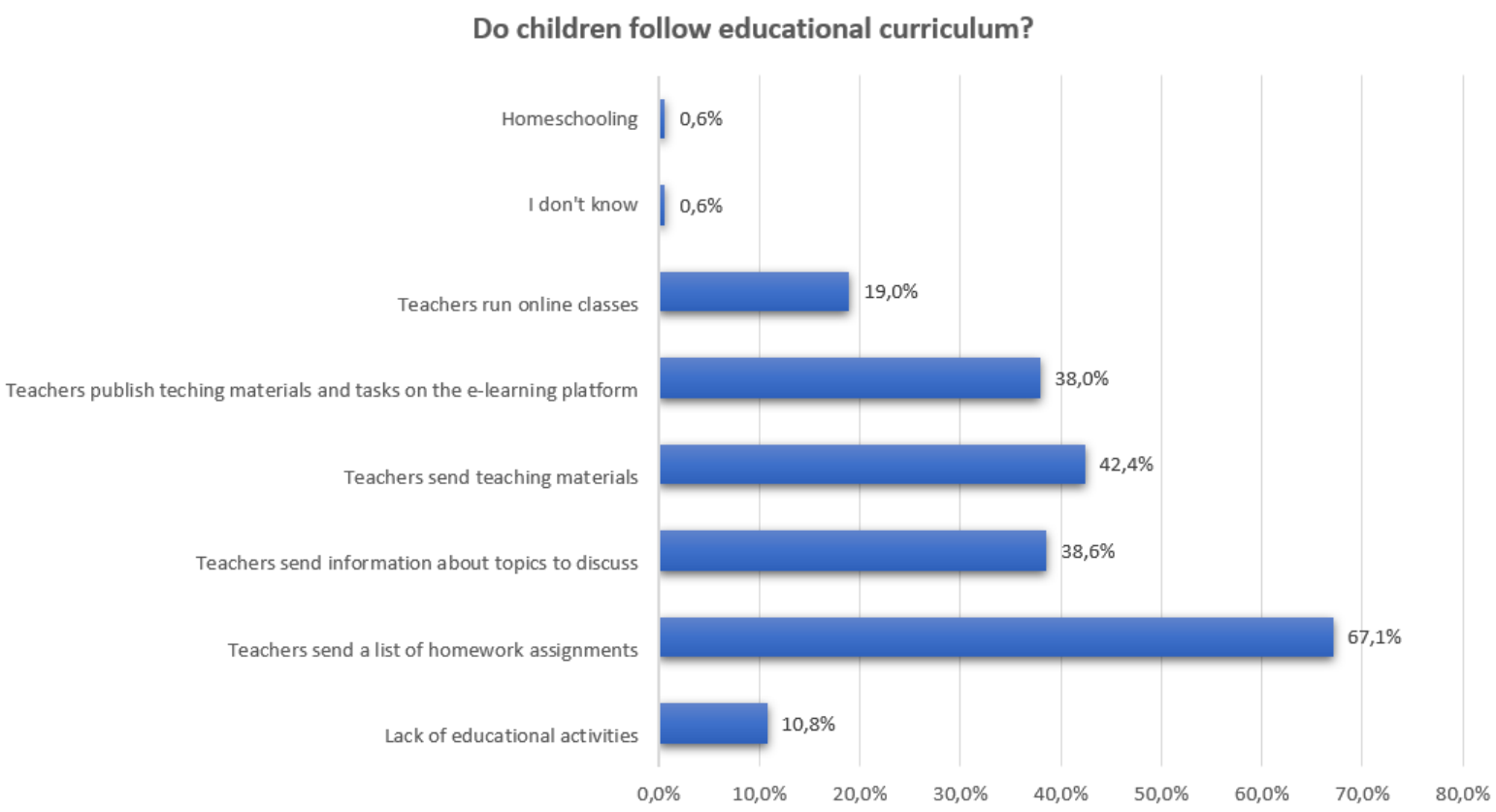

Source: own elaboration.

Figure 8. Do you allow children to go outside in this situation?

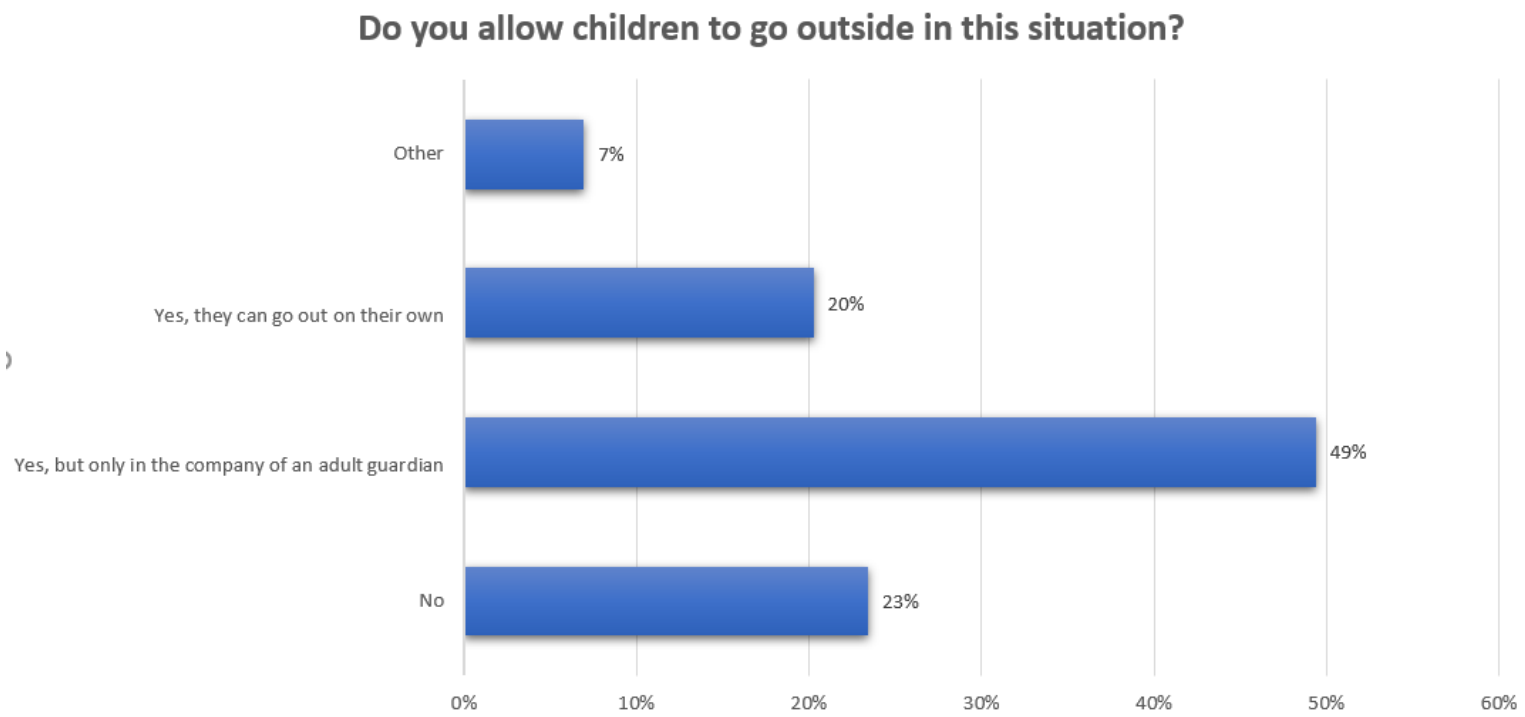

Source: own elaboration.

WHAT KIND OF SUPPORT WOULD YOU CONSIDER MOST NEEDED FOR PARENTS / CHILDREN IN THE CURRENT EPIDEMIOLOGICAL SITUATION?

According to one-third of the parents (28\%), more efficient organization of remote teaching would be the most important support. This would involve conducting online 
live classes, and not just sending tasks to be performed by children to their parents. In the parents' opinion, training for teachers in the use of digital tools would also be very much needed. In addition, parents drew attention to aspects such as psychological support that would help them understand how to deal with their own and their children's anxiety and how to explain to the children the requirements of the current situation and the restrictions imposed on them.

\section{ADDITIONAL REFLECTIONS OF PARENTS}

Among additional reflections provided by the parents prevail comments related to low digital competences and low implementation and use of technology both in the workplace and in the education system. This significantly hinders effective functioning in the situation of forced isolation and the necessity to stay at home. Some companies do not have procedures implemented for remote work, which means that employees are forced to travel to the company headquarters (this creates a problem with providing children with care and concerns about their health, possible infection and transmission of the virus at home).

A similar picture emerges from descriptions of cooperation with teachers. The parents' declarations show that most of the teachers (school and kindergarten) only send information about homework because they do not have the tools or competences to conduct 'live' classes, which would bring a number of benefits to students (direct contact with teachers and explanation of the material, possibility to keep in touch with classmates/groups and last but not least taking care of the child for a period of time, which would allow the parents to focus on work). There are voices suggesting that the implemented distance learning system should be top-down introduced by the authorities and adapted to the digital competences and equipment resources of parents, or educational institutions should be able to lend the necessary equipment (computers, tablets) to families in need free of charge. Unfortunately, to implement such solutions, equipment should be available and procedures should be developed for making it available.

\section{CONCLUSIONS}

The results of the study show the diverse problems faced by families in everyday life in the era of pandemic. The situation of children and the situation of parents who have been (without warning) ripped out of daily rituals and locked within four walls under one roof for several weeks is new to most of them. Despite widespread access to the media, information chaos can be observed causing a sense of insecurity among adults about the present situation and ways of coping with it. Information is directed mainly to adults by adults, overlooking the needs and perspectives of children. The media discourse lacks a safe space to inform all citizens, but who it particularly ignores are children and adolescents. Neither politicians nor journalists give children and youth a voice with their questions that would be answered by adults with competence and respect. Lack of information about whether secondary school final exams (Matura) 
will take place is the most glaring example of violating the rights of adolescents in the chaos of the pandemic. Temporary closure associated with a number of restrictions on existing civil rights has moved social and professional activities to the virtual world and immured families in the "four walls" in which family members try to negotiate a new rhythm of everyday life together. It must be added that the research results refer to a very short period of time. New restrictions were introduced on April $1^{\text {st }}$ in Poland and limited citizens' liberties and freedom of movement. They particularly affected are children and adolescents under the age of 18, who are not allowed to leave homes unaccompanied by an adult. Only the company of a parent, legal guardian or another adult caretaker can justify their presence in the street. The adult respondents focused on their own situation and the situation of children in the family in the limited space and with limited mobility. Spatial limitations and the sudden necessity to shift to professional and educational functioning in the virtual world, accentuated the absence of or imperfections in the area of digital competences and time management.

Adults working online or in company offices combine full-time jobs with childcare and assisting their children in learning and homework assignments. This situation has detrimental effects to all parties involved. This challenge requiring new skills, time management and adequate technological resources has proved to be problematic. Remote work tools turned out to be an obstacle as well (insufficient amount of equipment, Internet access).

As far as interpersonal relations are concerned, both adults and children suffer from the absence of social contact. This refers to both meetings with friends and visiting the children's grandparents (in the case of children - time spent with their peers from preschool or school).

The majority of the respondents did not report to have any strategy of explaining the present situation to their children. The parents declared that they informed the children about the situation and the necessity to maintain hygiene in an open and straightforward way, using simple words. Parents of very young children do not discuss the coronavirus with their sons and daughters. Some parents use fairy tales, metaphors or tales to explain the circumstances to their children in an accessible way, trying not to arouse fear. Of course, there were a few cases in which restrictions were imposed on children without any attempts to explain why they needed to be introduced.

Another aspect explored was to what degree the parents take into consideration/ are open to children's participation in developing new rules of conduct adjusted to the new situation and to what degree adults impose the new rules of daily functioning on their children. Only a small percentage of the parents reported that such new rules had been introduced. An even smaller group of the respondents replied that the new rules had been consulted with their children. The imposed social isolation resulted in circumstances in which parents, spending far more time with their children, take on additional activities. For parents working outside their homes, the intensified time spent together is simultaneously a source of more stress and accumulation of problems. It is primarily connected with exhaustion and considerable investment in helping their children with online education. 
Children's reactions to media information about the epidemic were an important aspect of the study. The parents reported that due to the omnipresent subject of the coronavirus in various media, they talked with their children, explained, and answered their questions. The second trend emerging from the parents' answers was to limit children's access to information about this sensitive subject to protect them.

The research results show the difficult situation - a situation that is new in every respect in families' daily functioning- both parents and children from our research sample have found themselves in. The questions "what, where and how" asked in the title of this article are not limited only to the dilemmas of adult-imposed prohibitions and orders within parents-children relations. These questions demand further exploration oriented towards the next stage of adapting to the difficult, unprecedented and simultaneously unpredictable situation in which extraordinary legal solutions should not lead to unjustified and arbitrary restrictions in rights, including the rights of children and adolescents that constitute a large part of Polish society.

\section{ORIGINALITY/VALUE}

Research can be helpful in understanding the situation of families with children in the age of pandemic that forced the reorganisation of family and professional life. The results show how the functioning of parents and children changed in the first phase of the coronavirus crisis, and what kind of help families would need most. The study can constitute a valuable source of information in creating adequate support mechanisms for families with children and developing recommendations for local authorities and educational institutions.

FUNDING: This research received no external funding.

CONFLICT OF INTEREST: The authors declare no conflict of interest.

\section{REFERENCES}

„Badanie e-czytelnictwa i rynku książki elektronicznej.” 2017. Instytut badawczy ARC Rynek i Opinia. Retrieved March 31, 2020 (http://lustrobiblioteki.pl/2017/03/badanie-e-czytelnictwa-rynku-ksiazki-elektronicznej/).

"Coronavirus (COVID-19): what you need to do." 2020. United Kingdom Government Digital Service. Retrieved March 30, 2020 (https://www.gov.uk/foreign-travel-advice/poland).

Głomb, Krzysztof and Anna Kniaź, eds. 2019. Kompetencje przyszłości w czasach cyfrowej dysrupcji. Studium wyzwań dla Polski w perspektywie roku 2030. Warszawa: Stowarzyszenie Miasta w Internecie, Fundacja Naukowa Evidence Institute. 
„Nauczyciele się starzeją.” 2019. Głos nauczycielski. Retrieved March 30, 2020 (https:// glos.pl/nauczyciele-sie-starzeja).

Głowacka, Ewa. 2011.” Jakość bibliotek cyfrowych - aspekty i kryteria oceny.” E-mentor nr 2 (39). Retrieved March 30, 2020 (http://www.e-mentor.edu.pl/artykul/index/numer/39/id/828 ).

Kacperczyk, Ewa and Beata Rzymek, eds. 2019. Information society in Poland in 2019. Warszawa, Szczecin: Główny Urząd Statystyczny (Central Statistics Office).

Liebel, Manfred. 2014. "Adultism and age-based discrimination against children." Pp. 119-143 in Children and non-discrimination: Interdisciplinary textbook edited by D. Kutsar, D. and H. Warming. Tartu: University of Estonia: CREAN.

Liebel, Manfred and Urszula Markowska-Manista. 2017. Prawa dziecka w kontekście międzykulturowości: Janusz Korczak na nowo odczytany. Warszawa: Wydawnictwo Akademii Pedagogiki Specjalnej im. M. Grzegorzewskiej.

Łoza Bartosz. 2020. „Psychiatra o kwarantannie: Załamanie emocji dopiero przed nami.” Rzeczpospolita. Retrieved March 31, 2020 (https://www.rp.pl/Koronawirus-SARS-CoV-2/303249907-Psychiatra-o-kwarantannie-Zalamanie-emocji-dopiero-przed-nami.html).

„Zdalne lekcje.” 2020. Ministerstwo Edukacji Narodowej. Retrieved March 31, 2020 (https://www.gov.pl/web/zdalnelekcje).

Unicef. 1989. "Convention on the Rights of the Child.” Retrieved March 31, 2020 (https://www.ohchr.org/en/professionalinterest/pages/crc.aspx ).

Sarzała, Dariusz and Wojciech Piestrzyński. 2015. „Młodzież i dzieci w cyberprzestrzeni a zagrożenia w sferze socjalizacji.” Konińskie Studia Społeczno-Ekonomiczne 1(2): $145-158$

Sewastianowicz, Monika. 2019. „Szkolny komputer zwykle nie pierwszej młodości.” Prawo.pl. Retrieved 30 March, 2020 (https://www.prawo.pl/oswiata/informatyka-i-sprzet-w-szkole-stanowisko-men,496754.html).

"Facts and figures 2019 Measuring digital development." 2019. Telecommunication Development Bureau. Retrieved March 31, 2020 (https://itu.foleon.com/itu/measuring-digital-development/ict-skills/ ).

Ziaja, Joanna. 2012. „Literatura elektroniczna a czytelnictwo młodzieży akademickiej.” Podkarpackie Studia Biblioteczne 1: 17-21.

Żebrok, Przemysław. 2018. „Wykorzystanie dziennika elektronicznego w praktyce szkolnej." EduAkcja. Magazyn edukacji elektronicznej 1(15): 41-57. 


\section{BIOGRAPHICAL NOTE}

Urszula Markowska-Manista, $\mathrm{PhD}$ - is field researcher in education in culturally diversified environments and indigenous childhood and youth studies concerning children's rights. Since 2016, she has been the director of and lecturer in the MA Childhood Studies and Children's Rights (MACR, Berlin, Potsdam) and is assistant professor at the University of Warsaw (Faculty of Education).

Dominika Zakrzewska-Olędzka, $\mathrm{PhD}$ - is an assistant professor at Institute of Psychology at The Maria Grzegorzewska University in Warsaw. Her main research interests concentrate on the correlates of prejudice and stereotypes and the process of shaping attitudes towards otherness. During last years she focuses on the situation of minorities in the Polish society and interculturality in Polish education system.

OPEN ACCESS: This article is distributed under the terms of the Creative Commons Attribution Non-commercial License (CC BY-NC 4.0) which permits any non-commercial use, and reproduction in any medium, provided the original author(s) and source are credited.

ARTICLE HISTORY: Received 2020-03-30 / Accepted 2020-04-11 
